\title{
REVIEW
}

\section{Tug of war in the haematopoietic stem cell niche: do myeloma plasma cells compete for the HSC niche?}

\author{
JE Noll ${ }^{1}$, SA Williams ${ }^{1}$, LE Purton ${ }^{2,3}$ and ACW Zannettino ${ }^{1,4}$
}

In the adult mammal, normal haematopoiesis occurs predominantly in the bone marrow, where primitive haematopoietic stem cells (HSC) and their progeny reside in specialised microenvironments. The bone marrow microenvironment contains specific anatomical areas (termed niches) that are highly specialised for the development of certain blood cell types, for example HSCs. The HSC niche provides important cell-cell interactions and signalling molecules that regulate HSC self-renewal and differentiation processes. These same signals and interactions are also important in the progression of haematological malignancies, such as multiple myeloma (MM). This review provides an overview of the bone marrow microenvironment and its involvement in normal, physiological HSC maintenance and plasma cell growth throughout MM disease progression.

Blood Cancer Journal (2012) 2, e91; doi:10.1038/bcj.2012.38; published online 14 September 2012

Keywords: myeloma; niche; bone microenvironment; haematopoietic stem cells

\section{THE HAEMATOPOIETIC STEM CELL NICHE}

The bone marrow stroma consists of non-haematopoietic cells such as fibroblasts, osteoblasts and their mesenchymal precursors including mesenchymal stem cells (MSC), pericytes, endothelial cells, adipocytes, nerves and the bone marrow vascular system. ${ }^{1-3}$ Furthermore, haematopoietic cell types, including macrophages, osteoclasts and T-lymphocytes, also produce cytokines and other factors that contribute to the function of the bone marrow microenvironment. These cells, and others, represent a microenvironment that is conducive to the growth and development of HSCs. The cellular composition of the HSC 'niche' and signals that contribute to HSC cellular quiescence, maintenance, mobilisation, homing and differentiation have been areas of intense investigation in recent years. ${ }^{4}$

The original concept of a haematopoietic niche (as described above) was proposed by Schofield et al., ${ }^{5}$ who observed that HSC growth was not supported in the spleen in the same manner as in the bone marrow. Indeed, it is now evident that in adult humans, normal haematopoiesis is restricted to the bone marrow. This concept has since been further developed, and it is now widely accepted that specific anatomical regions within the bone marrow comprise specialised niches for HSC development and normal blood cell production.

The HSC niche has diverse functionality, with significant interplay between signalling pathways allowing for the maintenance of a quiescent population of primitive HSC within the bone marrow, as well as subsequent HSC development and differentiation. Anatomically, there are two key HSC niches within the bone marrow; the endosteal niche, located adjacent to the bone surface, ${ }^{6,7}$ and the perivascular niche, located centrally within the bone marrow proximal to blood vessels. ${ }^{8}$ The endosteal niche is reported to be the primary location of quiescent HSCs, while the perivascular niche supports HSC mobilisation and differentiation., ${ }^{9,10} \mathrm{HSCs}$ isolated from the endosteal region of the bone marrow exhibit a higher self-renewal capacity than those from centralised (that is, perivascular) regions, ${ }^{11}$ indicating that endosteal HSCs are primarily involved in the self-renewal axis of HSC maintenance.

During HSC development, primitive HSCs are mobilised into the circulation and later re-enter the bone marrow space-a process commonly called homing. ${ }^{12,13}$ The endosteal surface of the bone is frequently identified as the region to which HSC homing and engraftment is directed. However, recent studies have identified stromal cells located within the perivascular niche as important for HSC homing and maintenance in the adult mouse. ${ }^{14-17}$ The discrepancies in these findings suggest that the precise location of HSCs during various stages of their developmental cycle is still an area of some controversy.

The cellular composition of the HSC niche, specifically cells of the mesenchymal lineage, and the roles they have in modulating HSC development has been an area of intense research in recent years. Greater understanding of the signalling processes and interactions that occur within and between these cell populations will enable us to better define changes and adaptations within the microenvironment that allow for neoplastic cell growth (discussed below).

\section{HSC NICHES AND DISEASE}

It has been suggested that specialised HSC niches are also involved in the development and progression of haematological malignancies. The extent of the reliance of these tumours on the microenvironment appears to be dependent upon the type and stage of malignancy. At one extreme is a neoplastic growth that is dependent on dysregulated cell-cell interactions and signalling pathways within the microenvironment. At the other end of the

\footnotetext{
${ }^{1}$ Myeloma Research Laboratory, Bone and Cancer Research Laboratories, Department of Haematology, Centre for Cancer Biology, Adelaide, South Australia, Australia; ${ }^{2}$ Stem Cell Regulation Unit, St Vincent's Institute, Fitzroy, Victoria, Australia; ${ }^{3}$ Department of Medicine, St Vincent's Hospital, The University of Melbourne, Fitzroy, Victoria, Australia and ${ }^{4}$ Centre for Personalised Cancer Medicine and Centre for Stem Cell Research, Faculty of Health Sciences, University of Adelaide, Adelaide, South Australia, Australia. Correspondence: Professor ACW Zannettino, Myeloma Research Laboratory, Bone and Cancer Research Laboratories, Department of Haematology, Centre for Cancer Biology, Adelaide, South Australia 5000, Australia.

E-mail: andrew.zannettino@health.sa.gov.au
}

Received 3 July 2012; revised 8 August 2012; accepted 14 August 2012 
spectrum are malignancies that exhibit an absolute dependence on normal microenvironmental cues for disease progression, such as the expression of specific cytokines and growth factors. ${ }^{18}$ Of the latter type of malignancy, multiple myeloma (MM) provides an ideal model to investigate the HSC bone marrow niche and to further define the mechanisms whereby B-cell neoplasms are able to utilise and potentially alter the normal HSC niche to provide a microenvironment conducive to neoplastic cell growth.

$\mathrm{MM}$ is a haematological malignancy that is characterised by the clonal proliferation of plasma cells within the bone marrow. Clinical manifestations of the disease include osteolytic bone lesions, hypercalcaemia, suppressed haematopoietic function and increased angiogenesis within the bone marrow. It is now widely accepted that most, if not all, MM is preceded by a premalignant disease known as monoclonal gammopathy of uncertain significance (MGUS). ${ }^{19}$ MGUS is characterised by the abnormal proliferation of plasma cells in the bone marrow, while the patients remain asymptomatic. ${ }^{20}$ The signals that lead to the initiation of excessive plasma cell proliferation are, therefore, present within the bone marrow microenvironment before the onset of overt MM. The transition of MGUS to MM requires further changes to the stromal compartment, which enhances myeloma cell growth and survival.

A number of pathways and cell types have been shown to affect the behaviour of both HSCs in normal haematopoiesis and the malignant myeloma plasma cells. It is through these regulated interactions with cell populations and signalling pathways within the bone marrow microenvironment that myeloma cells are believed to 'hijack' the normal hematopoietic niche to aid the extensive growth and proliferation of tumour cells ${ }^{18,21}$ (see Figure 1).

\section{B-CELL DEVELOPMENT AND PLASMA CELLS}

HSCs develop into a range of haematopoietic cell lineages, dependent on combinations of signals from the bone marrow stromal environment. B cells develop within a niche rich in cells of the osteoblastic and mesenchymal lineage. These cells express a range of factors required for the stimulation of B-cell survival and proliferation, including CXCL12, Flt-3 ligand, interleukin (IL)-7, integrins, vascular cell adhesion molecule 1 (VCAM-1) and $\mathrm{N}$-cadherin. ${ }^{22}$ Immature B cells migrate to secondary lymphoid organs where they are activated by exposure to antigen and subsequently differentiate into plasma cells and memory B cells. $^{23-25}$ These end-stage plasma cells have been shown to return to and colonise the bone marrow in specific niches adjacent to cells highly expressing CXCL12. ${ }^{26}$

CXCL12 was initially characterised as a pre-B-cell growth factor and its interaction with its receptor (CXCR4) has been shown to be absolutely required for B-cell development. ${ }^{27-30}$ Interestingly, the differentiation of $B$ cells towards the terminally differentiated plasma cell stage enhances the cells' sensitivity to CXCL12, which is most likely due to the high expression of CXCR4 on plasma cells. ${ }^{23,31,32}$ This increased sensitivity supports observations that mature plasma cells home to the bone marrow where stromal cells express high levels of CXCL12.

In addition, IL-6 expression by bone marrow stromal cells (BMSC) has been widely demonstrated to be required for haematopoiesis ${ }^{33-35}$ and more specifically to stimulate the differentiation of B cells into plasma cells, support plasma cell growth and protect plasma cells from apoptosis. ${ }^{36-39}$

\section{BMSC AND MM-A DEPENDENT RELATIONSHIP}

Normal plasma cells are dependent on specific signals from BMSCs to regulate their differentiation, growth and localisation. These same signals are required for myeloma cell growth and survival, supporting the notion that the bone marrow provides a permissive environment for disease development (see Figure 1).
A number of studies confirm the reliance of myeloma cells on interaction with the bone marrow stroma. The successful in vitro growth of murine-derived primary plasmacytomas demonstrated a reliance on stromal cell adhesion. ${ }^{40}$ Similarly, direct contact between BMSCs and myeloma cells is required to protect myeloma cells from drug-induced apoptosis, ${ }^{41-43}$ while a more recent study has identified an absolute reliance on the presence of BMSCs for the implantation and development of myeloma disease in mice. ${ }^{44}$ These cell-cell interactions have been demonstrated to induce the secretion of soluble factors by stromal cells, including IL- 6 and vascular endothelial growth factor (VEGF), which mediate survival and proliferative pathways. ${ }^{41,45,46}$ These studies establish the importance of interactions between myeloma cells and BMSCs for growth and survival of the malignant plasma cells. In addition, a recent report has suggested that the cellular source of a cytokine may result in a differential response to that cytokine. ${ }^{14}$ Therefore, the identification of which stromal cells that is (endothelial cells, osteoblasts or MSCs), secrete these factors may also be advantageous in determining the role these stromal cell-myeloma cell interactions and soluble factors have in mediating MM initiation and progression. It is evident that the presence of myeloma cells in the bone marrow modulates the expression of cytokines from stromal cells, which enhances their ability to modify the microenvironment to support malignant growth.

\section{HYPOXIA-AN IDEAL CONDITION FOR MM PLASMA CELL GROWTH}

The bone marrow is defined as a hypoxic space with low oxygen tension. Distinct niches within the bone marrow have also been demonstrated to display varying oxygen tension, with a greater degree of hypoxia evident at the endosteal niche, accompanied by increased expression of hypoxia-inducible factor- $1 \alpha^{47}$ These hypoxic conditions are ideal for the maintenance of HSC at the endosteal niche in a quiescent state and are required for controlled HSC development. ${ }^{48,49}$

The development and progression of $\mathrm{MM}$ is similar to solid tumours, and is accompanied by increased vascularisation and angiogenesis. The vascularisation observed in MM is largely due to the formation of microvessels within the hypoxic bone marrow environment, which is sufficient to increase the oxygen tension in the bone marrow and stimulate continued MM tumour growth (reviewed by Martin et $a l^{50}$ ). Using the 5TMM mouse model of myeloma disease, Asosingh et al., ${ }^{51}$ showed that myeloma plasma cell infiltration into the bone marrow was associated with a decrease in hypoxia, relative to the control. In addition, we have previously shown that the hypoxia-inducible factor, hypoxiainducible factor- $2 \alpha$, is aberrantly expressed by CD138+ MM plasma cells, resulting in enhanced angiogenesis. ${ }^{52}$ Together, these data infer that although MM initiation occurs in the hypoxic bone marrow environment, angiogenesis is subsequently stimulated and is required for continued MM tumour growth.

\section{CXCL12-A ROLE IN HSC DEVELOPMENT AND MM}

In addition to being required for $\mathrm{B}$-cell differentiation in the bone marrow, the CXCL12/CXCR4 axis is an important mechanism for the control of HSC homing and maintenance within the bone marrow, with high expression of CXCL12 acting as a chemoattractant for both primitive hematopoietic cells and mature, differentiated plasma cells. ${ }^{26,53} \mathrm{HSCs}$ are commonly located in close proximity to high expressers of CXCL12 $2^{16,17}$ and CXCL12 expression is required for colonisation of the bone marrow by hematopoietic progenitors during mouse embryogenesis. ${ }^{54}$ In addition, treatment with the potent CXCR4 receptor antagonist AMD3100 or suppression of CXCL12 expression results in mobilisation of HSCs from the bone marrow. ${ }^{55-57}$ Furthermore, forced mobilisation of HSC through treatment with granulocyte 
a

\section{BM Stromal Cell}

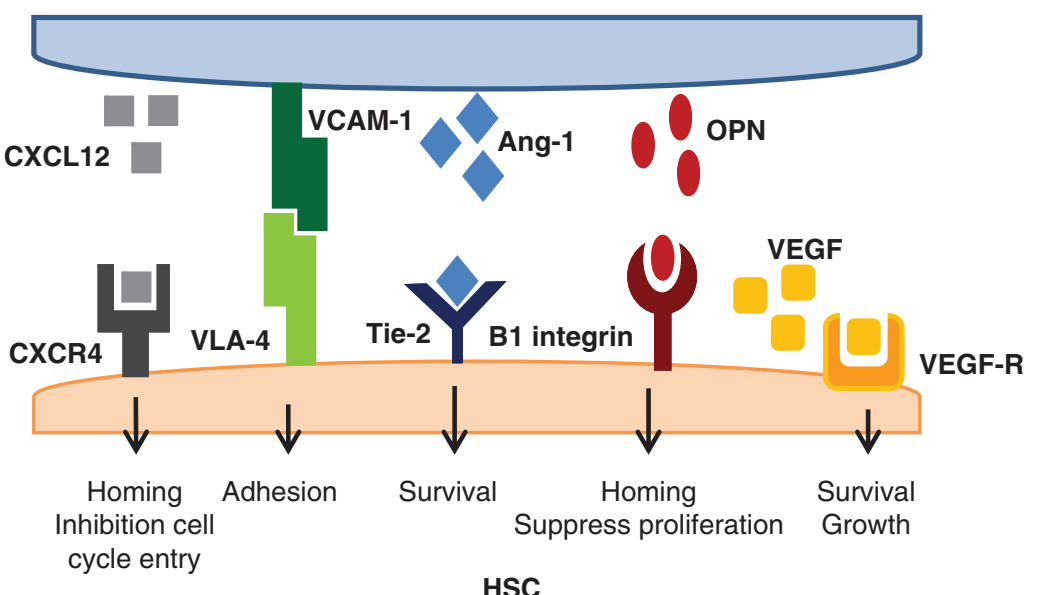

b

BM Stromal Cell

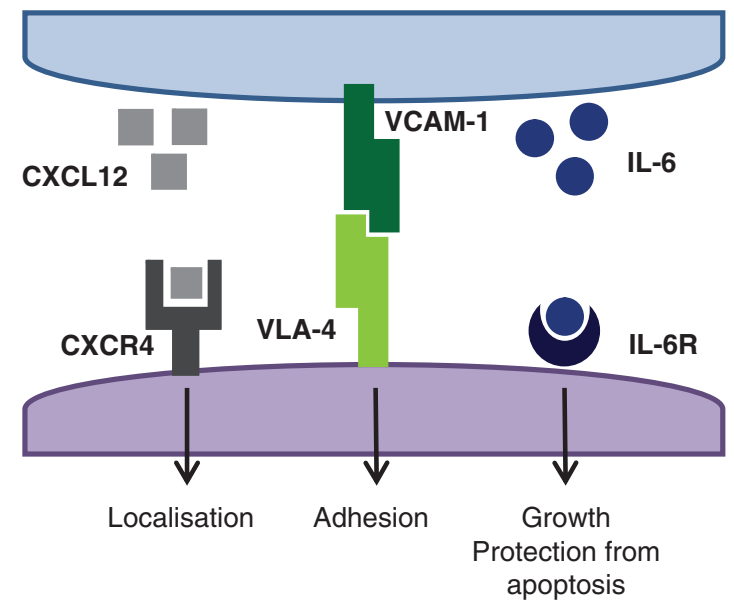

Plasma Cell

c

Angiogenesis

BM Stromal Cell

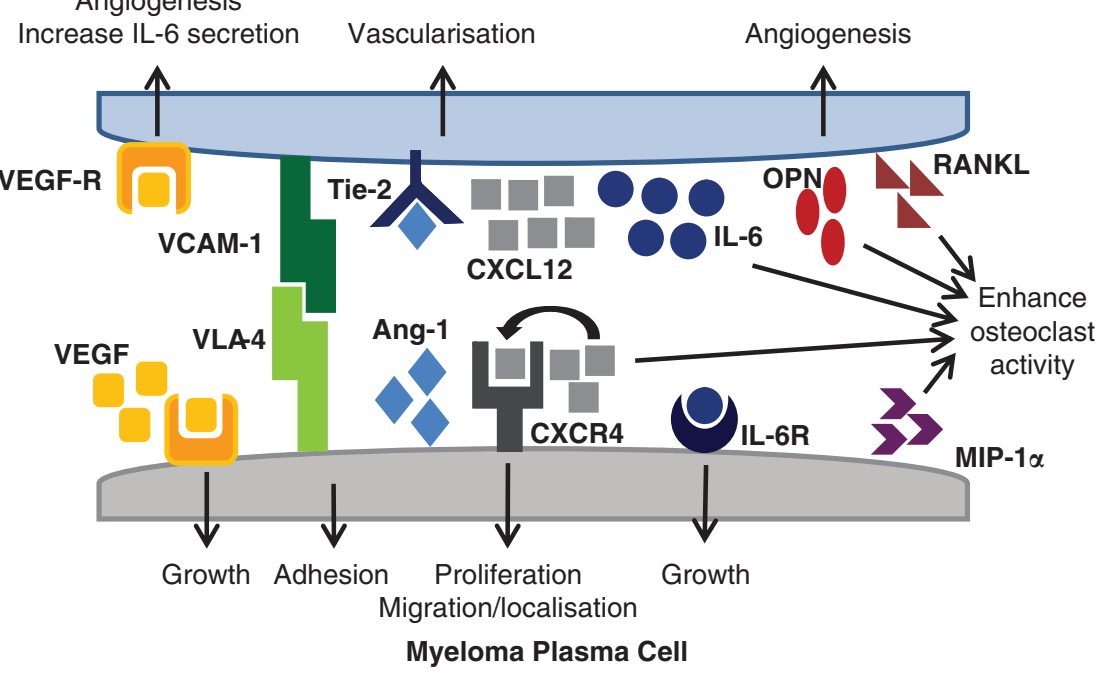

Figure 1. Schematic of BMSC interactions and signalling with HSC and plasma cells. Representative signalling/adhesion molecules and their role in bone marrow stromal cell interactions with (a) HSC, (b) normal plasma cells or (c) myeloma plasma cells.

colony-stimulating factor results in decreased levels of CXCL12 specifically within the bone marrow and inactivation of surface CXCR4. ${ }^{58,59}$
The role of CXCL12 in HSC maintenance also goes beyond its role as a chemoattractant for specific homing to the bone marrow niche, with addition of CXCL12 into culture inhibiting cell cycle 
entry of primitive HSCs. Conversely, inhibition of CXCR4 results in excessive proliferation of $\mathrm{HSCs}^{60}$ suggesting that $\mathrm{CXCL} 12$ signalling is also involved in maintaining the HSC quiescent state.

Similar to HSC, the homing of myeloma cells is responsive to signalling through the CXCL12/CXCR4 axis. Increased CXCL12 expression resulted in enhanced motility, while inhibition of CXCR4 blocked the directional homing of myeloma cells in vitro and in vivo and was concurrently found to be associated with decreased tumour burden. ${ }^{61,62}$ The role for CXCL12 in myeloma cell homing is supported by the observation that mobilisation of myeloma cells resulted in decreased surface expression and circulating levels of CXCR4 and CXCL12, respectively. ${ }^{63}$ Bone marrow endothelial cells isolated from MM patients also express higher levels of CXCL12, at both the mRNA and protein level, compared with those derived from healthy donors and this was shown to stimulate myeloma cell proliferation, which is in direct contrast to the effect of CXCL12 on inhibiting cell cycle entry of HSCs. ${ }^{60,64}$ In addition, we have previously shown that myeloma cells also express CXCL12, resulting in high circulating levels in the peripheral blood of MM patients. ${ }^{65,66}$ As CXCL12 acts as a chemoattractant and CXCR4 is known to be highly expressed on plasma cells, it is plausible that a CXCL12 paracrine signalling system between adjacent plasma cells may be involved in the development of plasmacytomas.

\section{IL-6-A B-CELL GROWTH FACTOR DURING HAEMATOPOIESIS AND MM DEVELOPMENT}

IL-6 is required for the differentiation and maintenance of plasma cells in the bone marrow (discussed above) and is also required for the growth and survival of myeloma cells. Initially, myeloma cells were shown to secrete IL-6, with their in vitro growth dependent on an intact IL-6 signalling pathway. ${ }^{67}$ Increased levels of IL-6 were also identified in the bone marrow of patients with $M M^{68}$ suggesting that myeloma cell growth is supported by cells within the bone marrow microenvironment through the production of IL-6. Indeed, more recently, myeloma cells were shown to stimulate increased expression of IL- 6 by MSCs within the bone microenvironment, while adhesion of myeloma cell lines to BMSC also stimulates expression of IL-6 from the stromal cells. ${ }^{46,69,70}$

The question remains whether an increase in IL-6 expression is sufficient to mediate a neoplastic change in plasma cell growth or whether it functions in concert with other signals to further compound malignant growth. IL-6 levels are tightly regulated and are generally maintained at low levels, although IL-6 is upregulated during inflammatory responses. Serum levels of IL- 6 have been demonstrated to be increased in mice and humans with advanced age, which is associated with chronic inflammatory disorders. ${ }^{71,72}$ Oestrogen deficiency, such as that observed in post menopausal women, is linked with an increase in IL-6 production associated with increased osteoclast activity and bone resorption. ${ }^{73,74}$ Similar effects have also been noted in androgen deficiency, however the inhibitory effect of androgens on IL-6 expression is less than that observed with oestrogen. ${ }^{75}$ This would explain the changes in IL- 6 secretion with advancing age and pose a potential mechanism through which increased IL-6 signalling may mediate MM growth and development. However, there remains a chicken and the egg scenario, in which it is unclear whether increased IL-6 signalling with age is sufficient to allow progression of MM disease, or whether the onset of $M M$ is an independent event resulting in an increase in IL-6 signalling within the bone marrow.

\section{ADHESION-VERY LATE ANTIGEN-4 AND VCAM-1}

The expression of a number of adhesion molecules by HSC is required for their specific homing and maintenance within the bone marrow. VLA-4 (also known as $\alpha 4 \beta 1$ integrin) has been shown to retain HSC within the bone marrow, ${ }^{63,76}$ through binding to VCAM-1, which is expressed within the bone marrow by both endothelial cells and osteoblasts. ${ }^{77,78}$ Mobilisation of HSC with granulocyte colony-stimulating factor results in decreased VLA-4 expression and cleavage of VCAM-1, while direct antagonism of VLA-4 though the small molecule inhibitor BIO5192 is sufficient to mediate mobilisation. ${ }^{79-81}$ These findings highlight the importance of this mechanism of adhesion in HSC maintenance within the bone marrow.

VLA-4 is also a major contributor to plasma cell interactions with the extracellular matrix and BMSC due to its predominant expression on the plasma cell surface. ${ }^{31,82}$ BMSC derived from patients with MM have been shown to exhibit higher expression of VCAM-1 compared with those from healthy donors which, in combination with the high levels of VLA-4 expressed by myeloma cells, mediates a preferential interaction between myeloma cells and stromal cells. ${ }^{41,83}$ These myeloma cell-stromal cell interactions allow the malignant cells to inhabit the same environment within the bone marrow normally utilised by HSC for their maintenance and development. The adhesion between myeloma cells and the bone marrow stroma is critical for myeloma development, as targeting of VLA-4 with a monoclonal antibody after the establishment of disease in a myeloma mouse model results in decreased tumour cell burden. ${ }^{84}$ The expression of VLA-4 on primitive haematopoietic cells, mature plasma cells and myeloma cells highlights a potentially important similarity between HSC and malignant plasma cells, which may lead to the presence of excessive myeloma cells within the bone marrow at the expense of normal HSC development.

\section{THE PERIVASCULAR HSC NICHE AND ANGIOGENIC FACTORS- FROM MAINTAINING HSC TO ENHANCING MM GROWTH}

Myeloma cell growth and the subsequent development of MM through enhanced angiogenesis is likely to occur through the hypoxia-inducible factor/VEGF/VEGF-R pathway. Indeed, this pathway was seen to be upregulated in $40 \%$ of MM cases and associated with increased angiogenesis and poor prognosis. ${ }^{85}$ Furthermore, studies from our laboratory have shown levels of CXCL12 in peripheral blood of MM and MGUS patients to positively correlate with the degree of bone marrow angiogenesis, which was associated with increased hypoxiainducible factor- $2 \alpha$ expression by MM plasma cells. ${ }^{52,65}$

VEGF has been shown to have an integral role in normal haematopoiesis with autocrine signalling required for both survival and growth of HSCs. ${ }^{86}$ VEGF is also expressed by myeloma cell lines and myeloma cells derived from MM patients ${ }^{87,88}$ and functions in both an autocrine and paracrine fashion to enhance cell growth and angiogenesis, with VEGF-R (VEGF receptor) expression detected on myeloma cells, as well as on BMSC from MM patients. ${ }^{89,90}$ This is further enhanced by the induced secretion of IL- 6 from stromal cells in response to VEGF, which in turn leads to greater plasma cell activation and growth. ${ }^{90,91}$

Osteopontin (OPN) and angiopoietin-1 (Ang-1) are factors expressed by osteoblasts at the bone surface that are required for osteoblastmediated HSC maintenance. ${ }^{92-94}$ Ang-1 binds its specific receptor, Tie-2, which is expressed on quiescent HSCs, resulting in maintenance of HSCs within the bone marrow. OPN was demonstrated to bind $\beta 1$ integrin, expressed on the HSC cell surface, and subsequently suppress HSC proliferation in vitro. OPN expression was also shown to be essential for directional homing of HSCs to the endosteal surface, as HSCs transplanted into Opn null mice were seen to be aberrantly scattered throughout the bone marrow. ${ }^{95,96}$

Ang-1 signalling is historically known for its role in vascularisation and angiogenesis, both in development and disease. ${ }^{97-101}$ Ang-1 is expressed by myeloma cells and is associated with upregulated expression of Tie-2 on bone marrow endothelial cells and increased vascularisation in vivo. ${ }^{102}$ Similarly, OPN has been 
described as a pro-angiogenic factor expressed by osteoclasts, which together with VEGF expressed by myeloma cells, functions to enhance osteoclast function and angiogenesis. ${ }^{103}$ In combination with IL-6, OPN has also been shown to enhance myeloma cell growth. ${ }^{104}$ The importance of OPN in mediating osteoclast function is evident as Opn knockout mice display minimal bone resorption compared with wild-type, an observation accompanied by decreased osteoclast association at the bone surface. ${ }^{105}$ Although OPN and Ang- 1 both have roles in HSC maintenance, it is increasingly evident that both these factors also have a role in the development of $\mathrm{MM}$ disease, including enhancing osteoclast activity and angiogenesis. Of particular interest is the observation that factors that are normally expressed within the bone marrow to specifically regulate and maintain the HSC niche are also involved in enhancing myeloma cell growth, supporting the notion that normal haematopoiesis, specifically maintenance of HSC within the bone marrow, is compromised throughout MM development and progression.

\section{MESENCHYMAL STEM CELLS}

MSC give rise to numerous cell types that are present within the bone marrow, including osteoblasts, adipocytes and chondrocytes, while also having an important role within the HSC niche. It is not yet clear if MSCs contribute to the endosteal HSC niche, the perivascular HSC niche or both. MSCs express high levels of cytokine-related genes, with evidence to suggest that the expression of CXCL12, SCF, IL-7 and VCAM-1 is greater from MSCs than from osteoblasts. ${ }^{15,106}$ The importance of MSC within the bone marrow niche in supporting HSC maintenance is evident as depletion of a specific population of nestin positive MSC resulted in a significant reduction in HSC homing and a concurrent increase in mobilisation. ${ }^{15}$ It remains unclear, however, whether these effects were due to depletion of MSC or the function of the sympathetic nervous system, which includes nestin positive cells. The signals generated by MSC that are involved in the maintenance of HSC in the bone marrow niche are also integral for the establishment and progression of MM disease.

Numerous studies have attempted to investigate the gene expression profiles of BMSC in MM patients. A recent study investigated gene expression profiles from MSCs and osteoblasts enriched from MM patients with or without lytic bone disease and found that there were no significant changes in gene expression from osteoblasts; however, a number of changes were identified in the primitive MSCs. ${ }^{107}$ The pathways modulated by MSCs in the presence of MM cells may therefore represent important mechanisms through which the bone marrow microenvironment contributes to MM disease development.

Gene expression relating to pathways specific to angiogenesis, inhibition of osteogenesis and tumour growth, and cell proliferation are enhanced in MSCs derived from MM patients, while genes involved in osteogenic differentiation pathways exhibit decreased expression. ${ }^{69,70,108,109}$ Functionally, MSC derived from MM patients exhibit a decreased capacity for osteogenic differentiation in vitro compared with those from healthy donors. ${ }^{108,110}$ In combination, these data suggest that myeloma cells alter the function of MSC through changes in gene expression profiles, while concurrently providing a mechanism whereby MSC may mediate MM disease progression.

In recent years, it has become increasingly evident that factors expressed by MSCs, particularly in the presence of MM disease, aid myeloma cell proliferation and survival, as well as providing proangiogenic stimulatory factors, which together create an environment conducive to the enhanced growth of malignant plasma cells. Therefore, it is plausible that an increase in the number of MSC would support the development of MM. Indeed the transplantation of murine MSCs following ex vivo expansion into a mouse model of myeloma resulted in decreased survival of mice, ${ }^{70}$ providing experimental evidence that an increase in the number of MSC may be directly involved in stimulating myeloma cell growth and the subsequent progression of MM disease. These data suggest that MSC may be a potential target for novel myeloma treatments, as decreasing the number of MSC and/or the signals produced by MSC in the course of MM disease progression may slow or halt disease development.

However, the effect of MM on MSC number in the bone marrow microenvironment is a current area of controversy. Historically, MSC have been isolated from BMSC using a method of plastic adherence. Using this method to isolate MSCs from bone marrow aspirates of healthy donors or patients with MM or MGUS, two independent studies have determined that there is no change ${ }^{108}$ or a decrease ${ }^{111}$ in MSC number with progression of MM. However, in a study which used a flow-cytometric approach to isolate MSC, a twofold increase in MSC number was seen in patients with MM compared with MGUS, although this finding was not significant. ${ }^{12}$ This suggests that the methods used to isolate MSC from bone marrow may bias results. Evidence to support this comes from two recent studies that investigated the tumourpromoting effects and phenotypes of MSCs isolated by plastic adherence. Studies from our laboratory investigated the properties of MSC following two independent methods of isolation. It was found that MSCs isolated by specific immunoselection were shown to have greater proliferative capacity, multilineage differentiation potential and clonogenicty than cells isolated by plastic adherence. ${ }^{113}$ In addition, plastic-adherent BMSC, which would typically contain the MSC population, were found to be contaminated with a population of myeloid precursor cells that exhibited independent gene expression patterns, phenotype and functional capabilities. ${ }^{114}$ As such the majority of studies that have investigated properties and gene expression profiles of MSC in MM are unreliable, owing to the presence of contaminating cells.

\section{IMPORTANT CELL TYPES IN THE ENDOSTEAL HSC NICHE- OSTEOBLASTS}

The differentiation of osteoblasts from MSCs occurs specifically within the bone marrow and is regulated by the RUNX2/CBFA1 transcription factor pathway, which is activated by collagen I binding to $\alpha 2 \beta 1$ integrin. ${ }^{15-117} \mathrm{Wnt} / \beta$-catenin signalling has also been demonstrated as critical for osteoblast differentiation ${ }^{118}$ with Wnt antagonists including Dickkopf-1 (DKK1) and secreted frizzled-related protein 2 specifically inhibiting the osteogenic differentiation of MSCs. ${ }^{19-122}$ In addition, both Hedgehog and Notch signalling pathways function to inhibit MSC differentiation towards the osteoblastic lineage. ${ }^{123-126}$

It has been suggested that cells of the osteoblastic lineage are critically involved in HSC maintenance at the endosteal niche. ${ }^{127}$ There are multiple lines of evidence to support this, including the expression of numerous factors by osteoblasts that are involved in HSC quiescence, homing and retention within the bone marrow. ${ }^{10,92,128-131}$ Furthermore, genetically altered mice that exhibit an increased number of osteoblasts are also observed to have a concurrent increase in HSC cell number, while the depletion of osteoblasts in this system results in HSC mobilisation. 6,7,132 Conversely, mobilisation of HSCs through treatment with granulocyte colony-stimulating factor results in a decrease in the number of osteoblasts present at the endosteal bone surface, which subsequently results in decreased expression of factors required for HSC retention. ${ }^{130}$ These observations all support a role for osteoblasts in maintaining the HSC niche. However, there is some debate surrounding the absolute requirement of osteoblasts in the HSC niche, as a recent study demonstrated that specific deletion of dicer in osteoprogenitor cells, but not in mature osteoblasts, disrupts normal haematopoiesis. ${ }^{133}$ 


\section{DYSREGULATION OF BONE REMODELLING IN MM-CONSEQUENCES ON HAEMATOPOIESIS}

Bone remodelling is constantly occurring at the endosteum, involving the cycling action of osteoclasts and osteoblasts. A major contributor to the osteolytic bone disease that frequently accompanies $\mathrm{MM}$ is deregulation of these bone remodelling pathways, with decreased formation and activity of osteoblasts accompanied by an increased number of active osteoclasts.

Human myeloma cells have been shown to inhibit MSC differentiation to the osteoblast lineage in bone marrow cultures, $^{120,134}$ as well as enhance osteoblast apoptosis in vitro. ${ }^{135,136}$ Osteoblasts derived from MM patients also exhibit an altered phenotype compared with those from healthy patients. ${ }^{110}$ Together, these studies indicate that there is significant impairment in the development of osteoblasts in patients with MM. In contrast, myeloma cells express a number of factors that contribute to the enhanced recruitment and activation of osteoclasts, including RANKL, macrophage inflammatory protein-1 $\alpha$, CXCL12 and IL-6. ${ }^{21,66,104,137-139}$

RANKL is expressed on the surface of BMSCs and osteoblasts and interacts with RANK (on the surface of osteoclasts precursors) to stimulate osteoclast formation and activity. ${ }^{140}$ In $\mathrm{MM}$, the expression of RANKL and its decoy receptor OPG is dysregulated, with increased RANKL and decreased OPG expression. ${ }^{141-143}$ The enhanced bone resorption observed in MM may also be attributed to an increase in IL- 6 and CXCL12 production by myeloma cells. Multiple studies have shown addition of IL-6 to long-term bone marrow stromal cultures to be sufficient for the formation of multinucleated cells phenotypically resembling osteoclasts and a subsequent increase in the rate of bone resorption, ${ }^{144,145}$ while increased CXCL12 enhances osteoclast motility and bone resorption. ${ }^{66,146}$ Increased osteoclast activity has also been demonstrated to function in a feed-forward loop to promote myeloma cell growth and survival. ${ }^{104,138}$

\section{DEREGULATED SIGNALLING PATHWAYS IN MM}

The Wnt signalling pathway functions through the inhibition of GSK3 $\beta$, which in turn leads to stabilisation of nuclear $\beta$-catenin and subsequent transcriptional activation of genes involved in osteoblastic differentiation. Utilising transgenic mouse models, two recent studies have identified the Wnt signalling pathway as integral in maintaining the quiescent HSC niche. The osteoblast specific expression of Wnt inhibitors Wif1 or Dkk1 in vivo resulted in increased proliferation of HSC in a microenvironment-dependent manner at the expense of self-renewal potential. ${ }^{147,148}$

There is, however, some controversy regarding the importance of Wnt signalling in myeloma disease pathogenesis. A number of studies show an increase in the expression of Wnt antagonists in MM, which have a significant role in the inhibition of bone formation, leading to myeloma-associated bone loss. ${ }^{44,120,122,149}$ In addition, studies from others have shown that myeloma cells display an active Wnt signalling pathway, which when further stimulated increases myeloma cell proliferation. ${ }^{150,151}$ A study by Edwards et al. ${ }^{152}$ has shown that while activation of the Wnt pathway enhances the growth of subcutaneously injected MM plasma cells in a mouse model of myeloma, this same activation within the bone microenvironment can prevent the development of myeloma bone disease and inhibit the growth of malignant plasma cells within the bone. This study emphasises the importance of acknowledging the role of the microenvironment in regulating $\mathrm{MM}$ disease when investigating new means of therapeutically targeting MM.

Active Notch signalling in HSC inhibits their differentiation, thereby maintaining HSC in an immature state. ${ }^{153,154}$ Notch signalling also maintains a population of progenitor MSC, while simultaneously inhibiting osteoblastic differentiation. ${ }^{124,125,155}$ In addition, excessive activation of Notch has been described in MM, resulting in increased secretion of MM plasma cell survival factors IL-6 and VEGF. ${ }^{156}$ Similarly, hedgehog signalling has been implicated in the initiation and clonal proliferation of progenitor cells, specifically cancer stem cells; ${ }^{157,158}$ however, its function in maintaining HSC is believed to be dispensable. ${ }^{159}$ Cancer stem cells are a rare subset of tumour cells capable of self-renewal, which have the ability to generate the highly heterogenous cells that comprise the tumour when transplanted into animal models. Cancer stem cells have been described in $\mathrm{MM}^{160-163}$ and it has been found that hedgehog activity is present specifically within the myeloma stem cell population, resulting in enhanced proliferation of these cells while having no effect on the differentiated plasma cells. ${ }^{164}$ In summary, the Wnt, Notch and Hedgehog signalling pathways represent possible targets for the development of future therapeutics, which may function to enhance the osteogenic differentiation of MSC. The validity of targeting the Wnt pathway is discussed below.

\section{WNT SIGNALLING IN MM-WNT ANTAGONISTS}

Wnt antagonists have been demonstrated to have a key role in MM disease pathogenesis. MM patients with lytic bone lesions were found to express secreted frizzled-related protein 2, identifying a possible mechanism through which Wnt signalling, and therefore osteoblast differentiation, may be inhibited. ${ }^{120}$ Gene expression analyses of plasma cells from MM patients with and without lytic bone disease also showed a significant increase in $D k k 1$ expression, accompanied by high DKK1 protein levels in MM patients, ${ }^{122,149}$ while DKK1 expression by BMSCs, including MSCs specifically, was also found to be increased in the presence of myeloma cells. ${ }^{44,70}$ DKK1 may be an integral factor for inhibiting osteoblastic differentiation of MSC in myeloma, as treatment of mice with an anti-Dkk1 antibody resulted in increased bone density accompanied by increased numbers of osteoblasts and decreased myeloma tumour burden. ${ }^{149}$ This function of DKK1 is further supported by studies which show that knockdown of $D k k 1$ expression in BMSCs reduced the ability of stromal cells to support myeloma disease in mice. ${ }^{44}$

Despite the expression of Wnt inhibitors in myeloma, direct inhibition of GSK3 $\beta$ by a small molecule inhibitor (6-bromoindirubin-3'-oxime) has been shown to improve bone quality and decrease tumour burden in an intratibial mouse model of myeloma. ${ }^{165}$ This study provides proof-of-principle that biological activation of the Wnt pathway in myeloma may provide a novel mechanism of disease treatment. However, it remains to be seen if the observed global effects of 6-bromoindirubin-3'-oxime treatment are due to a direct effect on the myeloma cells or whether it may also enhance osteoblastic differentiation in the surrounding bone marrow environment.

\section{CONCLUDING REMARKS}

In summary, the HSC niche is an ideal location for the initiation and development of MM. Common signalling pathways are utilised by both HSC and myeloma cells to mediate their localisation and proliferation. Paracrine and autocrine signalling through the CXCL12/CXCR4 and IL-6 axes is sufficient to mediate plasma cell proliferation, the development of plasmacytomas and the initiation of premalignant disease. It is also apparent that plasma cell-stromal cell interactions within the bone marrow microenvironment can elicit further changes in the stromal environment, altering the BMSC composition and subsequently the expression of signalling molecules which further support the growth and survival of myeloma cells. The characteristics of MM disease, including reduced immunoglobulin production, dysregulation of bone remodelling, hypercalcaemia and increased angiogenesis can all be attributed to stromal changes within the 
HSC niche that occur throughout the MGUS to MM disease transition. Although these stromal changes provide a means through which differences between MGUS and MM can be defined, the impact of these changes and their ability to mediate the transition of MGUS to MM is still unknown and warrants further investigation. Therapeutic targeting of these stromal cells within the bone marrow microenvironment, specifically MSCs and osteoblasts, may provide a novel mechanism of inhibiting MM disease progression.

\section{CONFLICT OF INTEREST}

The authors declare no conflict of interest.

\section{ACKNOWLEDGEMENTS}

LEP is an NHMRC Senior Research Fellow. LEP is the recipient of a project grant from NHMRC and is supported by the Victorian Government's Operational Infrastructure Support Program. ACWZ is supported by grants from the NHMRC, Cancer Australia, Leukaemia Foundation of Australia and the Cancer Council of South Australia.

\section{REFERENCES}

1 Kopp HG, Avecilla ST, Hooper AT, Rafii S. The bone marrow vascular niche: home of HSC differentiation and mobilization. Physiology 2005; 20: 349-356.

2 Krause DS. Regulation of hematopoietic stem cell fate. Oncogene 2002; 21: 3262-3269.

3 Kuehl WM, Bergsagel PL. Multiple myeloma: evolving genetic events and host interactions. Nat Rev Cancer 2002; 2: 175-187.

4 Purton LE, Scadden DT. The Hematopoietic Stem Cell Niche. Stem Book: Cambridge (MA), 2008.

5 Schofield R. The relationship between the spleen colony-forming cell and the haemopoietic stem cell. Blood Cells 1978; 4: 7-25.

6 Calvi LM, Adams GB, Weibrecht KW, Weber JM, Olson DP, Knight MC et al. Osteoblastic cells regulate the haematopoietic stem cell niche. Nature 2003; 425 : 841-846.

7 Zhang J, Niu C, Ye L, Huang H, He X, Tong WG et al. Identification of the haematopoietic stem cell niche and control of the niche size. Nature 2003; 425 836-841.

8 Kiel MJ, Yilmaz OH, Iwashita T, Terhorst C, Morrison SJ. SLAM family receptors distinguish hematopoietic stem and progenitor cells and reveal endothelial niches for stem cells. Cell 2005; 121: 1109-1121.

9 Shackney SE, Ford SS, Wittig AB. Kinetic-microarchitectural correlations in the bone marrow of the mouse. Cell Tissue Kinet 1975; 8: 505-516.

10 Xie Y, Yin T, Wiegraebe W, He XC, Miller D, Stark D et al. Detection of functional haematopoietic stem cell niche using real-time imaging. Nature 2009; 457: 97-101.

11 Grassinger J, Haylock DN, Williams B, Olsen GH, Nilsson SK. Phenotypically identical hemopoietic stem cells isolated from different regions of bone marrow have different biologic potential. Blood 2010; 116: 3185-3196.

12 Benveniste P, Cantin C, Hyam D, Iscove NN. Hematopoietic stem cells engraft in mice with absolute efficiency. Nat Immunol 2003; 4: 708-713.

13 Matsuzaki Y, Kinjo K, Mulligan RC, Okano H. Unexpectedly efficient homing capacity of purified murine hematopoietic stem cells. Immunity 2004; 20: 87-93.

14 Ding L, Saunders TL, Enikolopov G, Morrison SJ. Endothelial and perivascular cells maintain haematopoietic stem cells. Nature 2012; 481: 457-462.

15 Mendez-Ferrer S, Michurina TV, Ferraro F, Mazloom AR, Macarthur BD, Lira SA et al. Mesenchymal and haematopoietic stem cells form a unique bone marrow niche. Nature 2010; 466: 829-834

16 Omatsu Y, Sugiyama T, Kohara H, Kondoh G, Fujii N, Kohno K et al. The essential functions of adipo-osteogenic progenitors as the hematopoietic stem and progenitor cell niche. Immunity 2010; 33: 387-399.

17 Sugiyama T, Kohara H, Noda M, Nagasawa T. Maintenance of the hematopoietic stem cell pool by CXCL12-CXCR4 chemokine signaling in bone marrow stromal cell niches. Immunity 2006; 25: 977-988.

18 Burger JA, Ghia P, Rosenwald A, Caligaris-Cappio F. The microenvironment in mature B-cell malignancies: a target for new treatment strategies. Blood 2009; 114: 3367-3375.

19 Weiss BM, Abadie J, Verma P, Howard RS, Kuehl WM. A monoclonal gammopathy precedes multiple myeloma in most patients. Blood 2009; 113: 5418-5422.

20 Sirohi B, Powles R. Epidemiology and outcomes research for MGUS, myeloma and amyloidosis. Eur J Cancer 2006; 42: 1671-1683.
21 Heider U, Hofbauer LC, Zavrski I, Kaiser M, Jakob C, Sezer O. Novel aspects of osteoclast activation and osteoblast inhibition in myeloma bone disease. Biochem Biophys Res Commun 2005; 338: 687-693.

22 Nagasawa T. Microenvironmental niches in the bone marrow required for B-cell development. Nat Rev Immunol 2006; 6: 107-116.

23 Cyster JG. Homing of antibody secreting cells. Immunol Rev 2003; 194: 48-60.

24 Harwood NE, Batista FD. New insights into the early molecular events underlying B cell activation. Immunity 2008; 28: 609-619.

25 LeBien TW, Tedder TF. B lymphocytes: how they develop and function. Blood 2008; 112: 1570-1580.

26 Tokoyoda K, Egawa T, Sugiyama T, Choi Bl, Nagasawa T. Cellular niches controlling B lymphocyte behavior within bone marrow during development. Immunity 2004; 20: 707-718.

27 Egawa T, Kawabata K, Kawamoto H, Amada K, Okamoto R, Fujii N et al. The earliest stages of $\mathrm{B}$ cell development require a chemokine stromal cell-derived factor/pre-B cell growth-stimulating factor. Immunity 2001; 15: 323-334.

$28 \mathrm{Ma} Q$, Jones $\mathrm{D}$, Springer TA. The chemokine receptor CXCR4 is required for the retention of $B$ lineage and granulocytic precursors within the bone marrow microenvironment. Immunity 1999; 10: 463-471.

29 Nagasawa T, Hirota S, Tachibana K, Takakura N, Nishikawa S, Kitamura Y et al. Defects of B-cell lymphopoiesis and bone-marrow myelopoiesis in mice lacking the CXC chemokine PBSF/SDF-1. Nature 1996; 382: 635-638.

30 Nagasawa T, Kikutani H, Kishimoto T. Molecular cloning and structure of a pre-Bcell growth-stimulating factor. Proc Nat Acad Sci Usa 1994; 91: 2305-2309.

31 Calame KL. Plasma cells: finding new light at the end of B cell development. Nat Immunol 2001; 2: 1103-1108.

32 Hargreaves DC, Hyman PL, Lu TT, Ngo VN, Bidgol A, Suzuki G et al. A coordinated change in chemokine responsiveness guides plasma cell movements. J Exp Med 2001; 194: 45-56.

33 Ikebuchi K, Wong GG, Clark SC, Ihle JN, Hirai Y, Ogawa M. Interleukin 6 enhancement of interleukin 3-dependent proliferation of multipotential hemopoietic progenitors. Proc Nat Acad Sci USA 1987; 84: 9035-9039.

34 Okano A, Suzuki C, Takatsuki F, Akiyama Y, Koike K, Nakahata T et al. Effects of interleukin-6 on hematopoiesis in bone marrow-transplanted mice. Transplantation 1989; 47: 738-740.

35 Patchen ML, MacVittie TJ, Williams JL, Schwartz GN, Souza LM. Administration of interleukin- 6 stimulates multilineage hematopoiesis and accelerates recovery from radiation-induced hematopoietic depression. Blood 1991; 77: 472-480.

36 Gado K, Domjan G, Hegyesi H, Falus A. Role of INTERLEUKIN-6 in the pathogenesis of multiple myeloma. Cell Biol Int 2000; 24: 195-209.

37 Hirano $\mathrm{T}$, Yasukawa $\mathrm{K}$, Harada $\mathrm{H}$, Taga $\mathrm{T}$, Watanabe $\mathrm{Y}$, Matsuda $\mathrm{T}$ et al. Complementary DNA for a novel human interleukin (BSF-2) that induces B lymphocytes to produce immunoglobulin. Nature 1986; 324: 73-76.

38 Kawano MM, Mihara K, Huang N, Tsujimoto T, Kuramoto A. Differentiation of early plasma cells on bone marrow stromal cells requires interleukin-6 for escaping from apoptosis. Blood 1995; 85: 487-494.

39 Muraguchi A, Kishimoto T, Miki Y, Kuritani T, Kaieda T, Yoshizaki K et al. T cellreplacing factor- (TRF) induced IgG secretion in a human B blastoid cell line and demonstration of acceptors for TRF. J Immunol 1981; 127: 412-416.

40 Degrassi A, Hilbert DM, Rudikoff S, Anderson AO, Potter M, Coon HG. In vitro culture of primary plasmacytomas requires stromal cell feeder layers. Proc Nat Acad Sci USA 1993; 90: 2060-2064.

41 Hao M, Zhang L, An G, Meng H, Han Y, Xie Z et al. Bone marrow stromal cells protect myeloma cells from bortezomib induced apoptosis by suppressing microRNA-15a expression. Leuk Lymphoma 2011; 52: 1787-1794.

42 Nefedova Y, Landowski TH, Dalton WS. Bone marrow stromal-derived soluble factors and direct cell contact contribute to de novo drug resistance of myeloma cells by distinct mechanisms. Leukemia 2003; 17: 1175-1182.

43 Perez LE, Parquet N, Shain K, Nimmanapalli R, Alsina M, Anasetti C et al. Bone marrow stroma confers resistance to Apo2 ligand/TRAIL in multiple myeloma in part by regulating c-FLIP. J Immunol 2008; 180: 1545-1555.

44 Fowler JA, Mundy GR, Lwin ST, Edwards CM. Bone marrow stromal cells create a permissive microenvironment for myeloma development: a new stromal role for Wnt inhibitor Dkk1. Cancer Res 2012; 72: 2183-2189.

45 Gupta D, Treon SP, Shima Y, Hideshima T, Podar K, Tai YT et al. Adherence of multiple myeloma cells to bone marrow stromal cells upregulates vascular endothelial growth factor secretion: therapeutic applications. Leukemia 2001; 15: 1950-1961.

46 Uchiyama H, Barut BA, Mohrbacher AF, Chauhan D, Anderson KC. Adhesion of human myeloma-derived cell lines to bone marrow stromal cells stimulates interleukin-6 secretion. Blood 1993; 82: 3712-3720.

47 Levesque JP, Winkler IG, Hendy J, Williams B, Helwani F, Barbier V et al. Hematopoietic progenitor cell mobilization results in hypoxia with increased hypoxia-inducible transcription factor- 1 alpha and vascular endothelial growth factor A in bone marrow. Stem Cells 2007; 25: 1954-1965. 
48 Eliasson $\mathrm{P}$, Jonsson Jl. The hematopoietic stem cell niche: low in oxygen but a nice place to be. J Cell Physiol 2010; 222: 17-22.

49 Kubota Y, Takubo K, Suda T. Bone marrow long label-retaining cells reside in the sinusoidal hypoxic niche. Biochem Biophys Res Commun 2008; 366: 335-339.

50 Martin SK, Diamond P, Gronthos S, Peet DJ, Zannettino AC. The emerging role of hypoxia, HIF-1 and HIF-2 in multiple myeloma. Leukemia 2011; 25: 1533-1542.

51 Asosingh K, De Raeve H, de Ridder M, Storme GA, Willems A, Van Riet I et al. Role of the hypoxic bone marrow microenvironment in 5T2MM murine myeloma tumor progression. Haematologica 2005; 90: 810-817.

52 Martin SK, Diamond P, Williams SA, To LB, Peet DJ, Fujii N et al. Hypoxia-inducible factor-2 is a novel regulator of aberrant CXCL12 expression in multiple myeloma plasma cells. Haematologica 2010; 95: 776-784.

53 Wright DE, Wagers AJ, Gulati AP, Johnson FL, Weissman IL. Physiological migration of hematopoietic stem and progenitor cells. Science 2001; 294: 1933-1936.

54 Nagasawa T. A chemokine, SDF-1/PBSF, and its receptor, CXC chemokine receptor 4, as mediators of hematopoiesis. Int J Hematol 2000; 72: 408-411.

55 Broxmeyer HE, Orschell CM, Clapp DW, Hangoc G, Cooper S, Plett PA et al. Rapid mobilization of murine and human hematopoietic stem and progenitor cells with AMD3100, a CXCR4 antagonist. J Exp Med 2005; 201: 1307-1318.

56 Christopher MJ, Liu F, Hilton MJ, Long F, Link DC. Suppression of CXCL12 production by bone marrow osteoblasts is a common and critical pathway for cytokine-induced mobilization. Blood 2009; 114: 1331-1339.

57 Liles WC, Broxmeyer HE, Rodger E, Wood B, Hubel K, Cooper S et al. Mobilization of hematopoietic progenitor cells in healthy volunteers by AMD3100, a CXCR4 antagonist. Blood 2003; 102: 2728-2730.

58 Levesque JP, Hendy J, Takamatsu Y, Simmons PJ, Bendall LJ. Disruption of the CXCR4/CXCL12 chemotactic interaction during hematopoietic stem cell mobilization induced by GCSF or cyclophosphamide. J Clin Invest 2003; 111: 187-196.

59 Petit I, Szyper-Kravitz M, Nagler A, Lahav M, Peled A, Habler L et al. G-CSF induces stem cell mobilization by decreasing bone marrow SDF-1 and up-regulating CXCR4. Nat Immunol 2002; 3: 687-694.

60 Nie Y, Han YC, Zou YR. CXCR4 is required for the quiescence of primitive hematopoietic cells. J Exp Med 2008; 205: 777-783.

61 Alsayed Y, Ngo H, Runnels J, Leleu X, Singha UK, Pitsillides CM et al. Mechanisms of regulation of CXCR4/SDF-1 (CXCL12)-dependent migration and homing in multiple myeloma. Blood 2007; 109: 2708-2717.

62 Menu E, Asosingh K, Indraccolo S, De Raeve H, Van Riet I, Van Valckenborgh E et al. The involvement of stromal derived factor 1alpha in homing and progression of multiple myeloma in the 5TMM model. Haematologica 2006; 91 : 605-612.

63 Gazitt Y, Akay C. Mobilization of myeloma cells involves SDF-1/CXCR4 signaling and downregulation of VLA-4. Stem Cells 2004; 22: 65-73.

64 Pellegrino A, Ria R, Di Pietro G, Cirulli T, Surico G, Pennisi A et al. Bone marrow endothelial cells in multiple myeloma secrete CXC-chemokines that mediate interactions with plasma cells. Br J Haematol 2005; 129: 248-256.

65 Martin SK, Dewar AL, Farrugia AN, Horvath N, Gronthos S, To LB et al. Tumor angiogenesis is associated with plasma levels of stromal-derived factor-1alpha in patients with multiple myeloma. Clin Cancer Res 2006; 12: 6973-6977.

66 Zannettino AC, Farrugia AN, Kortesidis A, Manavis J, To LB, Martin SK et al. Elevated serum levels of stromal-derived factor-1alpha are associated with increased osteoclast activity and osteolytic bone disease in multiple myeloma patients. Cancer Res 2005; 65: 1700-1709.

67 Kawano M, Hirano T, Matsuda T, Taga T, Horii Y, Iwato K et al. Autocrine generation and requirement of BSF-2/IL- 6 for human multiple myelomas. Nature 1988; 332: 83-85.

68 Klein B, Zhang XG, Jourdan M, Content J, Houssiau F, Aarden L et al. Paracrine rather than autocrine regulation of myeloma-cell growth and differentiation by interleukin-6. Blood 1989; 73: 517-526.

69 Arnulf B, Lecourt S, Soulier J, Ternaux B, Lacassagne MN, Crinquette A et al. Phenotypic and functional characterization of bone marrow mesenchymal stem cells derived from patients with multiple myeloma. Leukemia 2007; 21: 158-163.

$70 \mathrm{Xu}$ S, Menu E, Becker AD, Van Camp B, Vanderkerken K, Van Riet I. Bone marrow-derived mesenchymal stromal cells are attracted by multiple myeloma cell-produced chemokine CCL25 and favor myeloma cell growth in vitro and in vivo. Stem Cells 2012; 30: 266-279.

71 Daynes RA, Araneo BA, Ershler WB, Maloney C, Li GZ, Ryu SY. Altered regulation of IL-6 production with normal aging. Possible linkage to the age-associated decline in dehydroepiandrosterone and its sulfated derivative. J Immunol 1993; 150: 5219-5230.

72 Ershler WB, Keller ET. Age-associated increased interleukin-6 gene expression, late-life diseases, and frailty. Annu Rev Med 2000; 51: 245-270.

73 Jilka RL, Hangoc G, Girasole G, Passeri G, Williams DC, Abrams JS et al. Increased osteoclast development after estrogen loss: mediation by interleukin-6. Science 1992; 257: 88-91.
74 Miyaura C, Kusano K, Masuzawa T, Chaki O, Onoe Y, Aoyagi M et al. Endogenous bone-resorbing factors in estrogen deficiency: cooperative effects of IL-1 and IL-6. J Bone Miner Res 1995; 10: 1365-1373.

75 Bellido T, Jilka RL, Boyce BF, Girasole G, Broxmeyer H, Dalrymple SA et al. Reg ulation of interleukin- 6 , osteoclastogenesis, and bone mass by androgens. The role of the androgen receptor. J Clin Invest 1995; 95: 2886-2895.

76 Priestley GV, Scott LM, Ulyanova T, Papayannopoulou T. Lack of alpha4 integrin expression in stem cells restricts competitive function and self-renewal activity. Blood 2006; 107: 2959-2967.

77 Jiang Y, Bonig H, Ulyanova T, Chang K, Papayannopoulou T. On the adaptation of endosteal stem cell niche function in response to stress. Blood 2009; 114 3773-3782.

78 Ulyanova T, Priestley GV, Nakamoto B, Jiang Y, Papayannopoulou T. VCAM-1 ablation in nonhematopoietic cells in MxCre + VCAM- $1 \mathrm{f} / \mathrm{f}$ mice is variable and dictates their phenotype. Exp Hematol 2007; 35: 565-571.

79 Cottler-Fox MH, Lapidot T, Petit I, Kollet O, DiPersio JF, Link D et al. Stem cell mobilization. Hematology Am Soc Hematol Educ Program 2003; 419-437.

80 Levesque JP, Takamatsu Y, Nilsson SK, Haylock DN, Simmons PJ. Vascular cell adhesion molecule-1 (CD106) is cleaved by neutrophil proteases in the bone marrow following hematopoietic progenitor cell mobilization by granulocyte colony-stimulating factor. Blood 2001; 98: 1289-1297.

81 Ramirez P, Rettig MP, Uy GL, Deych E, Holt MS, Ritchey JK et al. BIO5192, a smal molecule inhibitor of VLA-4, mobilizes hematopoietic stem and progenitor cells. Blood 2009; 114: 1340-1343.

82 Holt RU, Baykov V, Ro TB, Brabrand S, Waage A, Sundan A et al. Human myeloma cells adhere to fibronectin in response to hepatocyte growth factor. Haematologica 2005; 90: 479-488.

83 Michigami T, Shimizu N, Williams PJ, Niewolna M, Dallas SL, Mundy GR et al. Cellcell contact between marrow stromal cells and myeloma cells via VCAM-1 and alpha(4)beta(1)-integrin enhances production of osteoclast-stimulating activity. Blood 2000; 96: 1953-1960.

84 Olson DL, Burkly LC, Leone DR, Dolinski BM, Lobb RR. Anti-alpha4 integrin monoclonal antibody inhibits multiple myeloma growth in a murine model. Mol Cancer Ther 2005; 4: 91-99.

85 Giatromanolaki A, Bai M, Margaritis D, Bourantas KL, Koukourakis Ml, Sivridis E et al. Hypoxia and activated VEGF/receptor pathway in multiple myeloma. Anticancer Res 2010; 30: 2831-2836.

86 Gerber HP, Malik AK, Solar GP, Sherman D, Liang XH, Meng G et al. VEGF regulates haematopoietic stem cell survival by an internal autocrine loop mechanism. Nature 2002; 417: 954-958.

87 Colla S, Morandi F, Lazzaretti M, Polistena P, Svaldi M, Coser P et al. Do human myeloma cells directly produce basic FGF? Blood 2003; 102: author reply 3072-3073.

88 Kumar S, Witzig TE, Timm M, Haug J, Wellik L, Fonseca R et al. Expression of VEGF and its receptors by myeloma cells. Leukemia 2003; 17: 2025-2031.

89 Podar K, Tai YT, Davies FE, Lentzsch S, Sattler M, Hideshima T et al. Vascular endothelial growth factor triggers signaling cascades mediating multiple myeloma cell growth and migration. Blood 2001; 98: 428-435.

90 Vacca A, Ria R, Ribatti D, Semeraro F, Djonov V, Di Raimondo F et al. A paracrine loop in the vascular endothelial growth factor pathway triggers tumor angiogenesis and growth in multiple myeloma. Haematologica 2003; 88: 176-185.

91 Dankbar B, Padro T, Leo R, Feldmann B, Kropff M, Mesters RM et al. Vascular endothelial growth factor and interleukin- 6 in paracrine tumor-stromal cell interactions in multiple myeloma. Blood 2000; 95: 2630-2636.

92 Arai F, Hirao A, Ohmura M, Sato H, Matsuoka S, Takubo K et al. Tie2/angiopoietin1 signaling regulates hematopoietic stem cell quiescence in the bone marrow niche. Cell 2004; 118: 149-161.

93 Hsu HC, Ema H, Osawa M, Nakamura Y, Suda T, Nakauchi H. Hematopoietic stem cells express Tie-2 receptor in the murine fetal liver. Blood 2000; 96: 3757-3762.

94 Mayack SR, Wagers AJ. Osteolineage niche cells initiate hematopoietic stem cell mobilization. Blood 2008; 112: 519-531.

95 Nilsson SK, Johnston HM, Whitty GA, Williams B, Webb RJ, Denhardt DT et al. Osteopontin, a key component of the hematopoietic stem cell niche and regulator of primitive hematopoietic progenitor cells. Blood 2005; 106: 1232-1239.

96 Stier S, Ko Y, Forkert R, Lutz C, Neuhaus T, Grunewald E et al. Osteopontin is a hematopoietic stem cell niche component that negatively regulates stem cell pool size. J Exp Med 2005; 201: 1781-1791.

97 Morisada T, Kubota Y, Urano T, Suda T, Oike Y. Angiopoietins and angiopoietinlike proteins in angiogenesis. Endothelium 2006; 13: 71-79.

98 Reiss Y. Angiopoietins. Recent Results Cancer Res 2010; 180: 3-13.

99 Sato TN, Qin Y, Kozak CA, Audus KL. Tie-1 and tie-2 define another class of putative receptor tyrosine kinase genes expressed in early embryonic vascular system. Proc Nat Acad Sci USA 1993; 90: 9355-9358.

100 Suri C, Jones PF, Patan S, Bartunkova S, Maisonpierre PC, Davis S et al. Requisite role of angiopoietin-1, a ligand for the TIE2 receptor, during embryonic angiogenesis. Cell 1996; 87: 1171-1180. 
101 Suri C, McClain J, Thurston G, McDonald DM, Zhou H, Oldmixon EH et al. Increased vascularization in mice overexpressing angiopoietin-1. Science 1998; 282: 468-471.

102 Giuliani N, Colla S, Lazzaretti M, Sala R, Roti G, Mancini C et al. Proangiogenic properties of human myeloma cells: production of angiopoietin-1 and its potential relationship to myeloma-induced angiogenesis. Blood 2003; 102: 638-645.

103 Tanaka Y, Abe M, Hiasa M, Oda A, Amou H, Nakano A et al. Myeloma cellosteoclast interaction enhances angiogenesis together with bone resorption: a role for vascular endothelial cell growth factor and osteopontin. Clin Cancer Res 2007; 13: 816-823.

104 Abe M, Hiura K, Wilde J, Shioyasono A, Moriyama K, Hashimoto T et al. Osteoclasts enhance myeloma cell growth and survival via cell-cell contact: a vicious cycle between bone destruction and myeloma expansion. Blood 2004; 104: 2484-2491.

105 Asou Y, Rittling SR, Yoshitake H, Tsuji K, Shinomiya K, Nifuji A et al. Osteopontin facilitates angiogenesis, accumulation of osteoclasts, and resorption in ectopic bone. Endocrinology 2001; 142: 1325-1332.

106 Nakamura Y, Arai F, Iwasaki H, Hosokawa K, Kobayashi I, Gomei Y et al. Isolation and characterization of endosteal niche cell populations that regulate hematopoietic stem cells. Blood 2010; 116: 1422-1432.

107 Todoerti K, Lisignoli G, Storti P, Agnelli L, Novara F, Manferdini C et al. Distinct transcriptional profiles characterize bone microenvironment mesenchymal cells rather than osteoblasts in relationship with multiple myeloma bone disease. Exp Hematol 2010; 38: 141-153.

108 Corre J, Mahtouk K, Attal M, Gadelorge M, Huynh A, Fleury-Cappellesso S et al. Bone marrow mesenchymal stem cells are abnormal in multiple myeloma. Leukemia 2007; 21: 1079-1088.

109 Wang X, Zhang Z, Yao C. Angiogenic activity of mesenchymal stem cells in multiple myeloma. Cancer Invest 2011; 29: 37-41.

110 Gregoretti MG, Gottardi D, Ghia P, Bergui L, Merico F, Marchisio PC et al. Characterization of bone marrow stromal cells from multiple myeloma. Leuk Res 1994; 18: 675-682.

111 Garderet L, Mazurier C, Chapel A, Ernou I, Boutin L, Holy X et al. Mesenchymal stem cell abnormalities in patients with multiple myeloma. Leuk Lymphoma 2007; 48: 2032-2041.

112 Jones EA, English A, Kinsey SE, Straszynski L, Emery P, Ponchel F et al. Optimization of a flow cytometry-based protocol for detection and phenotypic characterization of multipotent mesenchymal stromal cells from human bone marrow. Cytometry B Clin Cytom 2006; 70: 391-399.

113 Psaltis PJ, Paton S, See F, Arthur A, Martin S, Itescu S et al. Enrichment for STRO-1 expression enhances the cardiovascular paracrine activity of human bone marrow-derived mesenchymal cell populations. J Cell Physiol 2010; 223: 530-540.

114 Dawson MR, Chae SS, Jain RK, Duda DG. Direct evidence for lineage-dependent effects of bone marrow stromal cells on tumor progression. Am J Cancer Res 2011; 1: 144-154.

115 Ducy P, Zhang R, Geoffroy V, Ridall AL, Karsenty G. Osf2/Cbfa1: a transcriptional activator of osteoblast differentiation. Cell 1997; 89: 747-754.

116 Franceschi RT, Xiao G, Jiang D, Gopalakrishnan R, Yang S, Reith E. Multiple signaling pathways converge on the Cbfa1/Runx2 transcription factor to regulate osteoblast differentiation. Connect Tissue Res 2003; 44(Suppl 1): 109-116.

117 Karsenty G, Ducy P, Starbuck M, Priemel M, Shen J, Geoffroy V et al. Cbfa1 as a regulator of osteoblast differentiation and function. Bone 1999; 25: 107-108.

$118 \mathrm{Hu} \mathrm{H}$, Hilton MJ, Tu X, Yu K, Ornitz DM, Long F. Sequential roles of Hedgehog and Wnt signaling in osteoblast development. Development 2005; 132: 49-60.

119 Alfaro MP, Vincent A, Saraswati S, Thorne CA, Hong CC, Lee E et al. sFRP2 suppression of bone morphogenic protein (BMP) and Wnt signaling mediates mesenchymal stem cell (MSC) self-renewal promoting engraftment and myocardial repair. J Biol Chem 2010; 285: 35645-35653.

120 Oshima T, Abe M, Asano J, Hara T, Kitazoe K, Sekimoto E et al. Myeloma cells suppress bone formation by secreting a soluble Wnt inhibitor, sFRP-2. Blood 2005; 106: 3160-3165.

121 Qiang YW, Barlogie B, Rudikoff S, Shaughnessy Jr JD . Dkk1-induced inhibition of Wnt signaling in osteoblast differentiation is an underlying mechanism of bone loss in multiple myeloma. Bone 2008; 42: 669-680.

122 Tian E, Zhan F, Walker R, Rasmussen E, Ma Y, Barlogie B et al. The role of the Wntsignaling antagonist DKK1 in the development of osteolytic lesions in multiple myeloma. N Engl J Med 2003; 349: 2483-2494.

123 Canalis E. Notch signaling in osteoblasts. Sci Signal 2008; 1: pe17.

124 Deregowski V, Gazzerro E, Priest L, Rydziel S, Canalis E. Notch 1 overexpression inhibits osteoblastogenesis by suppressing Wnt/beta-catenin but not bone morphogenetic protein signaling. J Biol Chem 2006; 281: 6203-6210.

125 Hilton MJ, Tu X, Wu X, Bai S, Zhao H, Kobayashi T et al. Notch signaling maintains bone marrow mesenchymal progenitors by suppressing osteoblast differentiation. Nat Med 2008; 14: 306-314.
126 Plaisant M, Fontaine C, Cousin W, Rochet N, Dani C, Peraldi P. Activation of hedgehog signaling inhibits osteoblast differentiation of human mesenchymal stem cells. Stem Cells 2009; 27: 703-713.

127 Adams GB, Scadden DT. The hematopoietic stem cell in its place. Nat Immunol 2006; 7: 333-337.

128 Ehninger A, Trumpp A. The bone marrow stem cell niche grows up: mesenchymal stem cells and macrophages move in. J Exp Med 2011; 208: 421-428.

129 Qian H, Buza-Vidas N, Hyland CD, Jensen CT, Antonchuk J, Mansson R et al. Critical role of thrombopoietin in maintaining adult quiescent hematopoietic stem cells. Cell Stem Cell 2007; 1: 671-684.

130 Winkler IG, Sims NA, Pettit AR, Barbier V, Nowlan B, Helwani F et al. Bone marrow macrophages maintain hematopoietic stem cell (HSC) niches and their depletion mobilizes HSCs. Blood 2010; 116: 4815-4828.

131 Yoshihara H, Arai F, Hosokawa K, Hagiwara T, Takubo K, Nakamura Y et al. Thrombopoietin/MPL signaling regulates hematopoietic stem cell quiescence and interaction with the osteoblastic niche. Cell Stem Cell 2007; 1: 685-697.

132 Visnjic D, Kalajzic Z, Rowe DW, Katavic V, Lorenzo J, Aguila HL. Hematopoiesis is severely altered in mice with an induced osteoblast deficiency. Blood 2004; 103: 3258-3264.

133 Raaijmakers MH, Mukherjee S, Guo S, Zhang S, Kobayashi T, Schoonmaker JA et al. Bone progenitor dysfunction induces myelodysplasia and secondary leukaemia. Nature 2010; 464: 852-857.

134 Giuliani N, Colla S, Morandi F, Lazzaretti M, Sala R, Bonomini S et al. Myeloma cells block RUNX2/CBFA1 activity in human bone marrow osteoblast progenitors and inhibit osteoblast formation and differentiation. Blood 2005; 106: 2472-2483.

135 Silvestris F, Cafforio P, Calvani N, Dammacco F. Impaired osteoblastogenesis in myeloma bone disease: role of upregulated apoptosis by cytokines and malignant plasma cells. Br J Haematol 2004; 126: 475-486.

136 Silvestris F, Cafforio P, Tucci M, Grinello D, Dammacco F. Upregulation of osteoblast apoptosis by malignant plasma cells: a role in myeloma bone disease. Br J Haematol 2003; 122: 39-52.

137 Farrugia AN, Atkins GJ, To LB, Pan B, Horvath N, Kostakis P et al. Receptor activator of nuclear factor-kappaB ligand expression by human myeloma cells mediates osteoclast formation in vitro and correlates with bone destruction in vivo. Cancer Res 2003; 63: 5438-5445.

138 Yaccoby S, Wezeman MJ, Henderson A, Cottler-Fox M, Yi Q, Barlogie B et al. Cancer and the microenvironment: myeloma-osteoclast interactions as a model. Cancer Res 2004; 64: 2016-2023.

139 Yaccoby S, Wezeman MJ, Zangari M, Walker R, Cottler-Fox M, Gaddy D et al. Inhibitory effects of osteoblasts and increased bone formation on myeloma in novel culture systems and a myelomatous mouse model. Haematologica 2006; 91: 192-199.

140 Lacey DL, Timms E, Tan HL, Kelley MJ, Dunstan CR, Burgess T et al. Osteoprotegerin ligand is a cytokine that regulates osteoclast differentiation and activation. Cell 1998; 93: 165-176.

141 Giuliani N, Bataille R, Mancini C, Lazzaretti M, Barille S. Myeloma cells induce imbalance in the osteoprotegerin/osteoprotegerin ligand system in the human bone marrow environment. Blood 2001; 98: 3527-3533.

142 Pearse RN, Sordillo EM, Yaccoby S, Wong BR, Liau DF, Colman N et al. Multiple myeloma disrupts the TRANCE/ osteoprotegerin cytokine axis to trigger bone destruction and promote tumor progression. Proc Nat Acad Sci USA 2001; 98: 11581-11586.

143 Seidel C, Hjertner O, Abildgaard N, Heickendorff L, Hjorth M, Westin J et al. Serum osteoprotegerin levels are reduced in patients with multiple myeloma with lytic bone disease. Blood 2001; 98: 2269-2271.

144 Kurihara N, Bertolini D, Suda T, Akiyama Y, Roodman GD. IL-6 stimulates osteoclast-like multinucleated cell formation in long term human marrow cultures by inducing IL-1 release. J Immunol 1990; 144: 4226-4230.

145 Tamura T, Udagawa N, Takahashi N, Miyaura C, Tanaka S, Yamada Y et al. Soluble interleukin-6 receptor triggers osteoclast formation by interleukin 6. Proc Nat Acad Sci USA 1993; 90: 11924-11928.

146 Diamond P, Labrinidis A, Martin SK, Farrugia AN, Gronthos S, To LB et al. Targeted disruption of the CXCL12/CXCR4 axis inhibits osteolysis in a murine model of myeloma-associated bone loss. J Bone Miner Res 2009; 24: $1150-1161$

147 Fleming HE, Janzen V, Lo Celso C, Guo J, Leahy KM, Kronenberg HM et al. Wnt signaling in the niche enforces hematopoietic stem cell quiescence and is necessary to preserve self-renewal in vivo. Cell Stem Cell 2008; 2: 274-283.

148 Schaniel C, Sirabella D, Qiu J, Niu X, Lemischka IR, Moore KA. Wnt-inhibitory factor 1 dysregulation of the bone marrow niche exhausts hematopoietic stem cells. Blood 2011; 118: 2420-2429.

149 Yaccoby S, Ling W, Zhan F, Walker R, Barlogie B, Shaughnessy Jr. JD . Antibodybased inhibition of DKK1 suppresses tumor-induced bone resorption and multiple myeloma growth in vivo. Blood 2007; 109: 2106-2111. 
150 Chim CS, Pang R, Fung TK, Choi CL, Liang R. Epigenetic dysregulation of Wnt signaling pathway in multiple myeloma. Leukemia 2007; 21: 2527-2536.

151 Derksen PW, Tjin E, Meijer HP, Klok MD, MacGillavry HD, van Oers MH et al. Illegitimate WNT signaling promotes proliferation of multiple myeloma cells. Proc Nat Acad Sci USA 2004; 101: 6122-6127.

152 Edwards CM, Edwards JR, Lwin ST, Esparza J, Oyajobi BO, McCluskey B et al. Increasing Wnt signaling in the bone marrow microenvironment inhibits the development of myeloma bone disease and reduces tumor burden in bone in vivo. Blood 2008; 111: 2833-2842.

153 Duncan AW, Rattis FM, DiMascio LN, Congdon KL, Pazianos G, Zhao C et al. Integration of Notch and Wnt signaling in hematopoietic stem cell maintenance. Nat Immunol 2005; 6: 314-322.

154 Suzuki T, Chiba S. Notch signaling in hematopoietic stem cells. Int J Hematol 2005; 82: 285-294.

155 Varnum-Finney B, Xu L, Brashem-Stein C, Nourigat C, Flowers D, Bakkour S et al. Pluripotent, cytokine-dependent, hematopoietic stem cells are immortalized by constitutive Notch1 signaling. Nat Med 2000; 6: 1278-1281.

156 Houde C, Li Y, Song L, Barton K, Zhang Q, Godwin J et al. Overexpression of the NOTCH ligand JAG2 in malignant plasma cells from multiple myeloma patients and cell lines. Blood 2004; 104: 3697-3704.

157 Merchant AA, Matsui W. Targeting Hedgehog--a cancer stem cell pathway. Clin Cancer Res 2010; 16: 3130-3140.

158 Taipale J, Beachy PA. The Hedgehog and Wnt signalling pathways in cancer. Nature 2001; 411: 349-354.
159 Gao J, Graves S, Koch U, Liu S, Jankovic V, Buonamici S et al. Hedgehog signaling is dispensable for adult hematopoietic stem cell function. Cell Stem Cell 2009; 4 548-558.

160 Hamburger A, Salmon SE. Primary bioassay of human myeloma stem cells. J Clin Invest 1977; 60: 846-854.

161 Park $\mathrm{CH}$, Bergsagel DE, McCulloch EA. Mouse myeloma tumor stem cells: a primary cell culture assay. J Natl Cancer Inst 1971; 46: 411-422.

162 Pilarski LM, Belch AR. Clonotypic myeloma cells able to xenograft myeloma to nonobese diabetic severe combined immunodeficient mice copurify with CD34 (+) hematopoietic progenitors. Clin Cancer Res 2002; 8: 3198-3204.

163 Reya T, Morrison SJ, Clarke MF, Weissman IL. Stem cells, cancer, and cancer stem cells. Nature 2001; 414: 105-111.

164 Peacock CD, Wang Q, Gesell GS, Corcoran-Schwartz IM, Jones E, Kim J et al. Hedgehog signaling maintains a tumor stem cell compartment in multiple myeloma. Proc Nat Acad Sci USA 2007; 104: 4048-4053.

165 Gunn WG, Krause U, Lee N, Gregory CA. Pharmaceutical inhibition of glycogen synthetase kinase-3beta reduces multiple myeloma-induced bone disease in a novel murine plasmacytoma xenograft model. Blood 2011; 117: 1641-1651.

This work is licensed under the Creative Commons AttributionSOMERIFHISRESERVED NonCommercial-No Derivative Works 3.0 Unported License. To view a copy of this license, visit http://creativecommons.org/licenses/by-nc-nd/3.0/ 